\title{
IDENTIFYING KEY SUCCESS FACTORS FOR INTERNATIONAL JOINT VENTURES IN CHINA: A FOREIGN PARENT PERSPECTIVE FROM FINNISH FIRMS
}

\author{
Xiaosong Zheng, Jorma Larimo
}

\section{Introduction}

International Joint Ventures (IJVs) have been in a central role of global expansion by several companies [64]. IJVs are formed between two or more firms with different organizational and cultural characteristics. There are several advantages related to the IJV entry mode like the possibility for the local and parent firms to exploit complementary resources, innovative capacities and core competencies (e.g. [17], [22], [35], [37], [45], [49], [52]). IJVs are superior when firms face uncertainty about the foreign market and future development or when information is inadequate [1]. Therefore IJVs are often used as a market entry approach by developed countries aiming to enter emerging markets where foreign firms usually face an uncertainty in economic and opportunistic behaviours. In spite of the high popularity of IJVs especially in emerging markets results in several studies have indicated that the goals set for the IJVs have not been reached and that there has been high rates of instability and failures in IJV operations [4], [24], [26], [57]. Thus there has been growing interest to study in more details the performance of IJVs and to study the key factors and drivers behind successful and unsuccessful IJVs.

When it comes to China IJVs have been rapidly proliferating in China in the last three decades since China adopted an open door policy to attract foreign investments in 1978. In addition to wholly foreign-owned firms, equity joint venture is a major mode of business operation [13]. According to U.S.-China
Business Council [65], Foreign Direct Investment (FDI) in China totalled $\$ 82.7$ billion by 2007 with a total of 37,888 new foreign invested firms. In recent years China has been popular among Nordic firms because of their limited domestic market and China's over 1.3 billion potential consumers together with the outstanding economic performance. However, many IJVs experience significant problems in China due to its complicated and difficult environment [8]. Therefore it is necessary to look into these problems, find solutions and identify key success factors for IJVs in China.

In the literature the research on SinoForeign IJVs has been clearly growing, but the results have been partly mixed and the studies have mainly focused on the IJV operations by Asian, especially Taiwan-based firms. Many studies also focused on IJVs with parent firms coming from big Western countries such as the USA. However, research focusing on IJV (and FDIs) by firms from smaller developed European economies like from Nordic countries, has been extremely limited so far. Furthermore, as in the decade award winning article of Journal of International Business Studies (JIBS) Madhok [51] argues that most existing research on IJV performance tends to focus on a few single factors such as ownership and a shift of focus to case studies to examine relational dynamics is encouraged. In this study we will use nine Finnish-Chinese IJVs to do detailed case studies to identify key factors for IJV success. Therefore this study contributes to the existing IJV literature by attempting to identify key success factors in Finnish-Chinese IJVs 
through detailed case studies. The research results will have implications to academic researchers, firms, professionals and government policy makers.

This paper is organized in the following way. In the first section a literature review on determinants of IJV performance is conducted. The second section is about research method and data collection. In the third section a conceptual model is built up as a framework for case studies. Case results are discussed in the fourth section. The final section is summary and conclusions, including also implications of the study, discussion of limitations of this research, together with recommendations for future research directions.

\section{Determinants of IJV Performance}

One of the main challenges in evaluating IJV success is the measurement of its performance. In the literature different theories have been used to study IJV performance including transaction cost economies [25], [35], [58], agency theory [12], [36], [61], resource-based view [15], [19], [53], social exchange theory [63], knowledge-based view [16], [63], behaviour perspective [20], [31], organizational learning logic [30], [32], [49], bargaining power theory [39], [66], institutional theory [41], contingency theory [56], and fairness theory [48]. Among these theories resourced-based view and knowledge-based view have most commonly been applied in IJV performance studies. Some good literature review articles on IJV performance have been published in business and management journals [54], [60], [62], [67]. The results of these studies will be referred to later in this paper.

Before we study factors or determinants of IJV performance it will naturally come up with the question what are the proper measures of IJV performance i.e. what are the criteria to evaluate an IJV performance? Some of the IJV measures used in previous studies include satisfaction, financial indicators, survival, duration, instability, and stock-market reaction [2], [23], [38], [47]. IJV performance measures can be classified into objective and subjective measures. The use of objective measures may fail to reflect the long-term goal of IJVs [22], [45]. On the other hand, using subjective measures in evaluating IJV success will have difficulties because they may contain biased opinions and they are generally not comparable [55]. However, e.g. Geringer and Hebert [22] have found that subjective and objective measures are highly correlated. Using a sample of UK IJVs, Glaister and Buckley [23] confirmed Geringer and Hebert's findings. Zhan and Luo [69] suggest that different IJV performance measures can be classified into two groups namely financial performance and competitive performance. Financial performance includes return on investment (ROI), return on assets (ROA), and revenue growth etc. while competitive performance includes all other measures such as sales level, market position and share, customer satisfaction, organizational reputation and product image, realization of long-term strategic goals [7]. In this study we will use a number of subjective measures to examine and compare IJV performance in China due to the limited number of cases available.

After we have taken proper IJV performance measures we can then investigate what factors or determinants will affect IJV performance? In the literature some significant factors have been identified and discussed that include control, ownership, commitment, culture, trust, etc. [14], [21], [33], [40], [44], [51], [54], [60], [62], [63], [67]. These important factors are briefly described in the following.

Control can be defined as the management process by which a parent's interests are protected. According to Geringer and Hebert [21], control refers to the process whereby one party influences, to different degrees, the behaviour and output of another party through the use of power, authority, and a wide range of bureaucratic, cultural, and informal mechanisms. These of control are widely regarded as critical for IJV performance [10], [21], [39], [50]. Through control a partner influences the joint venture to behave in ways that lead to attainment of the organization's objectives [9]. The ownership structure is a means of materializing the management control which is determined by the partners' bargaining power [40]. The share ownership structure of a joint venture cannot be determined unilaterally, but is usually an outcome of negotiations between the investing country and the host country. The greater the power one partner has, the higher the share of ownership the partner can obtain [24]. Commitment refers to the extent to which the partners are bound to the stability and 
success of the relationship [4]. This involves the assurance of commitment before embarking on a joint venture with a partner and the encouragement of commitment by the partner throughout the venture's life span. Mutual commitment creates a feeling of shared identity [43] and facilitates the development of mutual trust and voluntary cooperation between partner firms. Therefore mutual commitment reduces conflicts and increases cooperation between IJV partners and will also increase the feeling of fairness and stabilizes relationships between partners. Mutual commitment improves IJV performance both directly through its effect on aligning interest and indirectly through its effect on minimizing conflict. Trust between partners has also been revealed as an important factor that contributes to the success of IJVs [14], [33], [51] and it can be easily managed to facilitate the achievement of IJV objectives [3], [5].

Finally, culture is bound around IJVs all the time and some researchers argue that culture does affect IJV performance [41]. Culture has been defined by Hofstede [27] as "the collective programming of the mind which distinguishes the members of one human group from another". Hofstede identified originally four cultural dimensions (i.e. Power Distance, Uncertainty Avoidance, Individualism-Collectivism, and Masculinity-Feminity) and later on a fifth dimension - Long-Term Orientation - especially based on the Asian cultures [28]. The impact of culture on IJV performance has been the most extensively examined variable in previous research [38], [62]. Among the five cultural dimensions Power Distance and Individualism are particularly different between nations [11]. Lu and Lee [44] found that Power Distance is positively related to the satisfaction of senior managers in IJVs and Individualism is negatively related to the satisfaction of senior managers in IJVs. Because this study focuses on IJVs from only one single Western European country to China we cannot focus in more details on the impact of cultural distance on IJV performance. However, it can be stated that Finland and China are relatively far away from each other along all five dimensions [29].

In addition to the above important IJV performance determinants many others are also worth looking into. For this purpose we summarized all main potential IJV performance determinants and they are presented in the following Table 1.
We think that research on IJV performance determinants theoretically can be divided into three stages. The first stage of research is to examine IJV background information such as cultural, economic, political and technological dimensions from all partners particularly for the local partner or target partner. These factors mostly represent macro level or environmental factors in the local environment where IJVs are operated. In Table 1 these environmental factors include culture, economy, government policy, technology, infrastructure, labour, market potential, legal system, quality of life. Each factor is further explained in more detail. For example legal system factor means how efficient the local government can protect Intellectual Property as nowadays many high tech foreign firms are expanding east to China. Legal system also concerns government regulations on IJVs and the stability of these regulations. Quality of life factor includes cost of living in the target country, safety and social security system in the country. These issues may influence the establishment and operation of IJVs. Countries having poor quality of life tend to accept more FDIs and their bargaining power in IJVs tends to be weak.

The second stage for research on IJV performance determinants is to look situational factors at IJV formation stage. These situational factors reflect factual data from all partners at the time of IJV establishment. In Table 1 these factors include motivation of entry, firm size, partner selection, IJV experience, resource, time of entry, ownership structure, sales orientation, and long-term focus. For example resource can be divided to capital and non-capital resources. The resource factor usually determines ownership structure which is a well proven factor that will significantly affect IJV performance. Timing of entry may also influence IJV performance [70]. Foreign companies entering a target market earlier usually have first comer advantages over latecomers.

The third stage for research on IJV performance determinants is to examine factors related to IJV operation stage. In Table 1 we have commitment, bargaining power, control, trust, justice, conflict, conflict resolution, cooperation, and age of the IJV. These factors are well represented in the literature and they are classified further in explaining their meanings. However, research on factors such 


\begin{tabular}{|c|c|c|c|c|c|}
\hline \multicolumn{6}{|c|}{ Determinants of IJV Performance } \\
\hline \multicolumn{2}{|c|}{ 1. IJV Local Environment } & \multicolumn{2}{|c|}{ 2. IJV Formation Stage } & \multicolumn{2}{|c|}{ 3. IJV Operation Stage } \\
\hline Determinants/Drivers & Classification/Explanation & Determinants/Drivers & Classification/Explanation & Determinants/Drivers & Classification/Explanation \\
\hline Culture & $\begin{array}{l}\text { Organizational culture, } \\
\text { national culture, cultural } \\
\text { sensitivity }\end{array}$ & Motivation of entry & $\begin{array}{l}\text { Motivation to enter the } \\
\text { specific country, } \\
\text { motivations to establish } \\
\text { IJVs from both foreign and } \\
\text { local partners' sides, goal } \\
\text { congruity }\end{array}$ & Commitment & $\begin{array}{l}\text { Resources commitment, } \\
\text { psychological commitment, } \\
\text { level of commitment }\end{array}$ \\
\hline Economy & $\begin{array}{l}\text { Local country GDP, growth } \\
\text { rate of GDP, economic } \\
\text { policies }\end{array}$ & Firm size & $\begin{array}{l}\text { Foreign parent firm size, } \\
\text { local partner firm size }\end{array}$ & Bargaining power & $\begin{array}{l}\text { Resource-based power, } \\
\text { context-based power }\end{array}$ \\
\hline Government policy & $\begin{array}{l}\text { Stability of government } \\
\text { policies, cooperation and } \\
\text { efficiency of local } \\
\text { government }\end{array}$ & Partner selection & $\begin{array}{l}\text { How to find a local partner? } \\
\text { How to evaluate and select } \\
\text { a local partner? }\end{array}$ & Control & $\begin{array}{l}\text { Strategic control, operational } \\
\text { control, structure control, } \\
\text { output control, process } \\
\text { control, social control }\end{array}$ \\
\hline Technology & $\begin{array}{l}\text { Technology available, } \\
\text { technology and knowledge } \\
\text { transfer }\end{array}$ & IJV experience & $\begin{array}{l}\text { Prior FDI and IJV } \\
\text { experiences both in the } \\
\text { local country and } \\
\text { internationally }\end{array}$ & Trust & $\begin{array}{l}\text { Interpartner trust, } \\
\text { interpersonal trust, trust } \\
\text { between partners and local } \\
\text { and foreign governments. }\end{array}$ \\
\hline Infrastructure & $\begin{array}{l}\text { Logistics and transportation } \\
\text { system, telecommincation } \\
\text { capacity }\end{array}$ & Resource & $\begin{array}{l}\text { Capital resources, non- } \\
\text { capital resources }\end{array}$ & Justice & $\begin{array}{l}\text { Distributive justice, } \\
\text { procedure justice, } \\
\text { interactional justice }\end{array}$ \\
\hline Labor & $\begin{array}{l}\text { Labor skills, labor } \\
\text { availability, labor attitude, } \\
\text { wage level }\end{array}$ & Timing of entry & $\begin{array}{l}\text { When to establish IJVs } \\
\text { affects IJV performance, } \\
\text { early entry vs. late entry }\end{array}$ & Conflict & $\begin{array}{l}\text { Task conflict, relationship } \\
\text { conflict, conflict resolution }\end{array}$ \\
\hline Market potential & $\begin{array}{l}\text { Market size, market type, } \\
\text { local competition level, } \\
\text { consumer confidence level }\end{array}$ & Ownership structure & $\begin{array}{l}\text { Percentage of share of } \\
\text { ownership, equity and non- } \\
\text { equity share of ownership }\end{array}$ & Conflict resolution & $\begin{array}{l}\text { Joint problem solving, } \\
\text { forcing, domination, } \\
\text { compromising }\end{array}$ \\
\hline Legal system & $\begin{array}{l}\text { IP protection, local } \\
\text { government regulations and } \\
\text { legal protection }\end{array}$ & Sales orientation & $\begin{array}{l}\text { Sales directed to a target } \\
\text { country or countrties }\end{array}$ & Cooperation & $\begin{array}{l}\text { Cooperation between } \\
\text { partners, cooperation } \\
\text { between partners and local } \\
\text { and foreign governments }\end{array}$ \\
\hline Quality of life & $\begin{array}{l}\text { cost of living, safety and } \\
\text { social security system }\end{array}$ & Long-term focus & $\begin{array}{l}\text { Intended duration of IJVs, } \\
\text { short-term vs. long-term } \\
\text { focus }\end{array}$ & Age of the IJV & $\begin{array}{l}\text { Age of the IJV unit, age of } \\
\text { partner relationships }\end{array}$ \\
\hline
\end{tabular}

Source: own

as justice is quite new and it deserves further research. Age of the IJV unit may also influence the IJV performance. Units having operated longer have reached the stability in operation and partner relationships thus may lead to better performance.

Table 1 gives a concise summary trying to capture all major IJV performance determinants. The table is built from research results in the literature as well as our own research. In a later section we will develop a concept model based on the determinants summarized in Table 1 to carry out case studies.

\section{Research Method and Data Collection}

This paper aims to identify key success factors for IJVs in China by using nine Finnish-Chinese IJVs operating in Mainland China. For this purpose a comparative case study research method is used. The cases are selected from a more extensive study focusing on the IJV behaviour, strategies and performance of Finnish firms made in late 2006 and early 2007. In this study we will examine the performance and key success factors of IJVs in China. Based on the examination and evaluation of the key factors a concept model will be constructed to 
systematically investigate the key determinants of IJV performance in China. Case study research method is also used for exploratory theory development and validation [68]. Case study can enable researchers to generate a rich understanding of the research question from a small number of situations while using a range of data collection methods [18].

The nine IJVs were established during 1994-2005 in China. Two of the nine IJVs had as a minority shareholder also another Finnish partner (a financing organization agreed to participate to ownership in a short term). Furthermore, in three IJVs there were two Chinese partners whereas the rest have only one Chinese partner. Two of the cases had the first manufacturing FDIs by the Finnish company and five of the cases had first IJVs by the companies. The Finnish equity share is between $10-90 \%$, thus fulfilling the traditional JV requirement for share. Some researchers regard only $50-50 \%$ ventures as the real IJVs. There was only one IJV of this kind among the nine cases and also in general the $50-50 \%$ IJVs seem to be very rare among IJVs by Finnish companies [38]. From the eight other IJVs three were originally minority and five majority owned by the Finnish partners. The motives establishing the IJVs were to increase profits and market share as well as lower production and sourcing costs [34]. Except in one case the IJVs were clearly established to last for longer time period, in several cases at least ten years.

\section{Fig. 1: A concept model for identifying key IJV performance determinants}

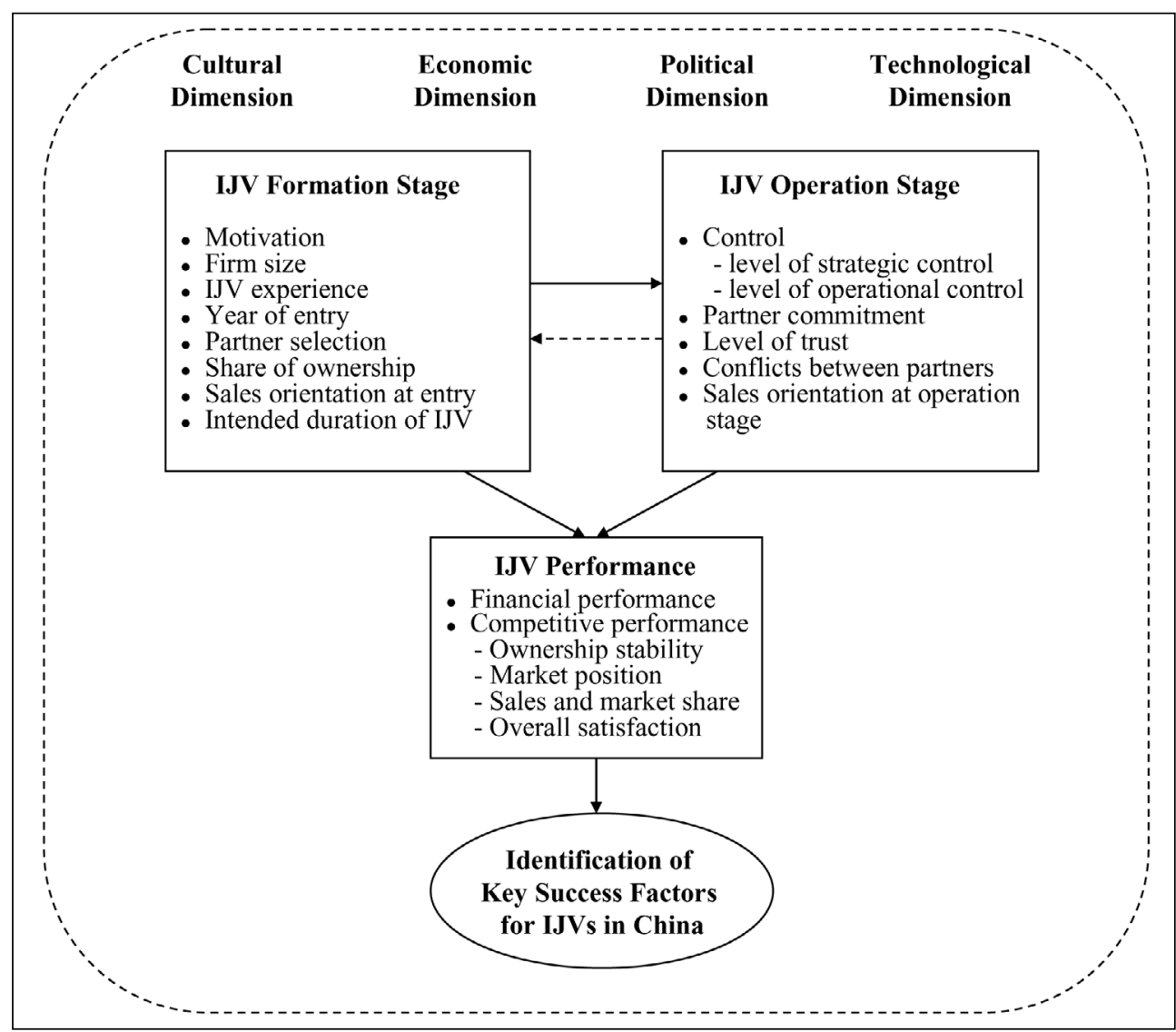

Source: own elaboration 


\section{The Concept Model Development}

In order to systematically study the key determinants of IJV performance, we developed a conceptual model to investigate determinants of performance in the nine Finnish-Chinese IJVs. The model is illustrated in the following Figure 1. Those on top of the model represent IJV local environmental factors and they are expressed as cultural, economic, political and technological dimensions. These are macro level factors rooted in the local parent country that will affect IJV performance. Next we identified a few most significant IJV performance determinants at IJV formation stage and IJV operation stage respectively. In Table 1, there is a more complete list of determinants at each stage. However, in practice we are not able to examine and test all factors and instead we have to select a few most important factors to test their influence on IJV performance [59]. It would not be feasible to test all factors in small scale case studies [6]. Below IJV formation and IJV operation stages, is the IJV performance. In this study we use subjective performance measures such as financial performance (ROI), ownership stability, market position, sales and

\section{Tab. 2: Results of key determinants at IJV formation stage}

\begin{tabular}{|c|c|c|c|c|c|c|c|c|c|}
\hline \multicolumn{10}{|c|}{ CASES } \\
\hline & $\mathbf{A}$ & B & $\mathrm{C}$ & D & $\mathbf{E}$ & $\mathbf{F}$ & G & $\mathbf{H}$ & I \\
\hline $\begin{array}{l}\text { Size of the Finnish } \\
\text { firm at the time of } \\
\text { entry (Meur) }\end{array}$ & 240 & 2,314 & 25 & 3 & 237 & 99 & 2357 & 2478 & 20 \\
\hline Field of industry & $\begin{array}{c}\text { Industrial } \\
\text { product }\end{array}$ & $\begin{array}{c}\text { Industrial } \\
\text { product }\end{array}$ & $\begin{array}{c}\text { Industrial } \\
\text { product }\end{array}$ & $\begin{array}{c}\text { Industrial } \\
\text { product }\end{array}$ & $\begin{array}{c}\text { Industrial } \\
\text { product }\end{array}$ & $\begin{array}{l}\text { Industrial } \\
\text { product }\end{array}$ & $\begin{array}{c}\text { Industrial } \\
\text { product }\end{array}$ & $\begin{array}{c}\text { Industrial } \\
\text { product }\end{array}$ & $\begin{array}{c}\text { Industrial } \\
\text { product }\end{array}$ \\
\hline FDI experience & 3 & 92 & 1 & 1 & 3 & 5 & 65 & 67 & 2 \\
\hline IJV experience & 1 & 10 or more & none & none & none & none & $5-9$ & $2-4$ & none \\
\hline Timing of entry & 2001 & 1999 & 1995 & 1994 & 2003 & 1999 & 2003 & 2005 & 2002 \\
\hline Establishment mode & Greenfield & Greenfield & Greenfield & Greenfield & Acquisition & Greenfield & Acquisition & Greenfield & Greenfield \\
\hline Earlier TC experience & none & exporting & other operations & no prior activity & $\begin{array}{c}\text { a wholly-owned } \\
\text { manufacturing } \\
\text { unit }\end{array}$ & exporting & $\begin{array}{l}\text { licensing } \\
\text { agreement }\end{array}$ & \begin{tabular}{|c|} 
Licensing \\
agreement, \\
exporting, \\
wholly-owned \\
manufacturing \\
unit, \\
manufacturing \\
JV, other \\
operations
\end{tabular} & $\begin{array}{c}\text { exporting, sales } \\
\text { subsidiary }\end{array}$ \\
\hline $\begin{array}{l}\text { Earlier partner } \\
\text { experience }\end{array}$ & competitor & $\begin{array}{c}\text { no prior } \\
\text { relationship }\end{array}$ & $\begin{array}{c}\text { no prior } \\
\text { relationship }\end{array}$ & $\begin{array}{l}\text { no prior } \\
\text { relationship }\end{array}$ & $\begin{array}{c}\text { no prior } \\
\text { relationship }\end{array}$ & $\begin{array}{l}\text { a licensing } \\
\text { partner }\end{array}$ & competitor & competitor & $\begin{array}{c}\text { no prior } \\
\text { relationship }\end{array}$ \\
\hline $\begin{array}{l}\text { Partner size } \\
\text { symmetry }\end{array}$ & $\begin{array}{c}\text { company bigger } \\
11-49 \% \text { than } \\
\text { partner }\end{array}$ & $\begin{array}{c}\text { company at least } \\
50 \% \text { bigger than } \\
\text { partner }\end{array}$ & $\begin{array}{c}\text { partners same } \\
\text { sized }(+/-10 \%)\end{array}$ & $\begin{array}{l}\text { company at least } \\
50 \% \text { smaller } \\
\text { than partner }\end{array}$ & $\begin{array}{c}\text { company at least } \\
50 \% \text { bigger than } \\
\text { partner }\end{array}$ & $\begin{array}{c}\text { company at least } \\
50 \% \text { bigger than } \\
\text { partner }\end{array}$ & $\begin{array}{c}\text { company at least } \\
50 \% \text { smaller } \\
\text { than partner }\end{array}$ & $\begin{array}{c}\text { company at least } \\
50 \% \text { bigger than } \\
\text { partner }\end{array}$ & n.a. \\
\hline Main motivation & $\begin{array}{c}\text { Earn profit, } \\
\text { Increase market } \\
\text { share, } \\
\text { Economies of } \\
\text { scale }\end{array}$ & $\begin{array}{c}\text { Earn profit, } \\
\text { Increase market } \\
\text { share, Achieve } \\
\text { rapid market } \\
\text { entry, Access to } \\
\text { local distribution } \\
\text { channel }\end{array}$ & $\begin{array}{c}\text { Earn profit, } \\
\text { Develop base for } \\
\text { low cost } \\
\text { sourcing, }\end{array}$ & $\begin{array}{c}\text { Increase market } \\
\text { share }\end{array}$ & $\begin{array}{c}\text { Earn profit, } \\
\text { Access to local } \\
\text { marketing } \\
\text { expertice, } \\
\text { Achieve } \\
\text { economies of } \\
\text { scale, Achieve } \\
\text { rapid market } \\
\text { entry, Access to } \\
\text { local distribution } \\
\text { channel }\end{array}$ & $\begin{array}{c}\text { Earn profit, } \\
\text { Increase market } \\
\text { share, Establish } \\
\text { a base to access } \\
\text { other countries }\end{array}$ & $\begin{array}{c}\text { Earn profit, } \\
\text { Increase market } \\
\text { share }\end{array}$ & $\begin{array}{c}\text { Earn profit, } \\
\text { Increase market } \\
\text { share, Develop } \\
\text { base for low cost } \\
\text { sourcing, } \\
\text { Achieve Quanxi- } \\
\text { relations }\end{array}$ & $\begin{array}{c}\text { Lower } \\
\text { production costs }\end{array}$ \\
\hline $\begin{array}{l}\text { Sales orientation of } \\
\text { the IJV at the entry } \\
\text { stage }\end{array}$ & $\begin{array}{c}75-100 \% \text { of the } \\
\text { total sales } \\
\text { directed to the } \\
\text { target country } \\
\end{array}$ & \begin{tabular}{|c}
$75-100 \%$ of the \\
total sales \\
directed to the \\
target country \\
\end{tabular} & $\begin{array}{c}0-4 \% \text { of the total } \\
\text { sales directed to } \\
\text { the target } \\
\text { country }\end{array}$ & $\begin{array}{l}75-100 \% \text { of the } \\
\text { total sales } \\
\text { directed to the } \\
\text { target country }\end{array}$ & $\begin{array}{c}75-100 \% \text { of the } \\
\text { total sales } \\
\text { directed to the } \\
\text { target country }\end{array}$ & $\begin{array}{c}0-4 \% \text { of the total } \\
\text { sales directed to } \\
\text { the target } \\
\text { country }\end{array}$ & \begin{tabular}{|c|}
$5-24 \%$ of the \\
total sales \\
directed to the \\
target country
\end{tabular} & \begin{tabular}{|c|}
$75-100 \%$ of the \\
total sales \\
directed to the \\
target country
\end{tabular} & $\begin{array}{c}100 \% \text { of the tota } \\
\text { sales directed to } \\
\text { the target } \\
\text { country }\end{array}$ \\
\hline $\begin{array}{l}\text { Finnish share of } \\
\text { ownership at entry }\end{array}$ & $51 \%$ & $49 \%$ & $25 \%$ & $25 \%$ & $85 \%$ & $60 \%$ & $55 \%$ & $50 \%$ & $55 \%$ \\
\hline $\begin{array}{l}\text { Intended duration of } \\
\text { the IJV }\end{array}$ & indefinite & $\begin{array}{l}\text { more than } 10 \\
\text { years }\end{array}$ & $\begin{array}{l}\text { more than } 10 \\
\text { years }\end{array}$ & $\begin{array}{c}\text { more than } 10 \\
\text { years }\end{array}$ & $2-5$ years & $\begin{array}{c}\text { more than } 10 \\
\text { years }\end{array}$ & $\begin{array}{l}\text { more than } 10 \\
\text { years }\end{array}$ & indefinite & $5-10$ years \\
\hline
\end{tabular}


market share, and overall satisfaction. The last part in the concept model is the conclusion of key success factors or determinants of IJV performance in China. As we mentioned earlier, these key success factors represent a Finnish parent perspective.

\section{Case Result}

In this study we focus on studying the factors associated with IJV formation and IJV operation stages. The results on these factors from case studies are presented in Table 2 and Table 3.

In Table 2, the nine IJV companies are numbered alphabetically from $A$ to $I$. The left column contains a few important factors at IJV formation stage such as Finnish firm size (in terms of value of assets), FDI and IJV expe- riences, year of investment and investment type, earlier trading company and partner experiences, partner size symmetry, main motivation and sales orientation at entry stage, Finnish percentage share of ownership at entry, and intended duration of the IJV.

In Table 3, results of key determinants at IJV operation stage are summarized. These determinants represent important factors associated with IJV performance in actual daily operations. These factors have been studied widely in the literature. Therefore we also emphasize these factors in this study. The control factor is divided into strategic control and operational control. Other important factors include commitment, trust, conflicts, sales orientation at operation stage, and total sales.

\section{Tab. 3: Results of key determinants at IJV operation stage}

\begin{tabular}{|c|c|c|c|c|c|c|c|c|c|}
\hline \multicolumn{10}{|c|}{ CASES } \\
\hline & $\mathbf{A}$ & B & $\mathrm{C}$ & D & $\mathbf{E}$ & $\mathbf{F}$ & G & $\mathbf{H}$ & $\mathbf{I}$ \\
\hline $\begin{array}{l}\text { Level of strategic } \\
\text { control }\end{array}$ & $\begin{array}{c}\text { High control over } \\
\text { major decisions } \\
\text { of the JV }\end{array}$ & $\begin{array}{c}\text { Relatively high } \\
\text { control over } \\
\text { major decisions } \\
\text { of the JV }\end{array}$ & $\begin{array}{c}\text { High control over } \\
\text { major decisions } \\
\text { of the JV }\end{array}$ & $\begin{array}{c}\text { High control over } \\
\text { major decisions } \\
\text { of the JV }\end{array}$ & $\begin{array}{c}\text { High control over } \\
\text { major decisions } \\
\text { of the JV }\end{array}$ & $\begin{array}{c}\text { Relatively high } \\
\text { control over } \\
\text { major decisions } \\
\text { of the JV }\end{array}$ & $\begin{array}{c}\text { Relatively high } \\
\text { control over } \\
\text { major decisions } \\
\text { of the JV }\end{array}$ & $\begin{array}{c}\text { Medium level of } \\
\text { control over } \\
\text { major decisions } \\
\text { of the JV }\end{array}$ & $\begin{array}{c}\text { High control over } \\
\text { major decisions } \\
\text { of the JV }\end{array}$ \\
\hline $\begin{array}{l}\text { Level of operational } \\
\text { control }\end{array}$ & $\begin{array}{c}\text { Relatively low } \\
\text { control over daily } \\
\text { activities of the } \\
\text { JV }\end{array}$ & $\begin{array}{c}\text { Relatively low } \\
\text { control over daily } \\
\text { activities of the } \\
\text { JV }\end{array}$ & $\begin{array}{c}\text { High control over } \\
\text { daily activitites } \\
\text { of the JV }\end{array}$ & $\begin{array}{c}\text { Medium level of } \\
\text { control over daily } \\
\text { activities of the } \\
\text { JV }\end{array}$ & $\begin{array}{c}\text { High control over } \\
\text { daily activitites } \\
\text { of the JV }\end{array}$ & $\begin{array}{c}\text { Medium level of } \\
\text { control over daily } \\
\text { activities of the } \\
\text { JV }\end{array}$ & $\begin{array}{c}\text { Relatively low } \\
\text { control over daily } \\
\text { activities of the } \\
\text { JV }\end{array}$ & $\begin{array}{c}\text { Relatively high } \\
\text { control over daily } \\
\text { activities of the } \\
\text { JV }\end{array}$ & $\begin{array}{c}\text { High control over } \\
\text { daily activitites } \\
\text { of the JV }\end{array}$ \\
\hline Partner commitment & \begin{tabular}{|} 
Partners are \\
relatively \\
strongly \\
committed to the \\
JV operation
\end{tabular} & $\begin{array}{c}\text { Partncrs have } \\
\text { medium level of } \\
\text { commitment to } \\
\text { the JV operation }\end{array}$ & $\begin{array}{c}\text { Partners have } \\
\text { low commitment } \\
\text { to the JV } \\
\text { operation }\end{array}$ & $\begin{array}{c}\text { Partners have } \\
\text { medium level of } \\
\text { commitment to } \\
\text { the JV operation }\end{array}$ & $\begin{array}{c}\text { Partners are } \\
\text { relatively } \\
\text { strongly } \\
\text { committed to the } \\
\text { JV operation }\end{array}$ & $\begin{array}{c}\text { Partners have } \\
\text { low commitment } \\
\text { to the JV } \\
\text { operation }\end{array}$ & $\begin{array}{c}\text { Partners are } \\
\text { relatively } \\
\text { strongly } \\
\text { committed to the } \\
\text { JV operation }\end{array}$ & $\begin{array}{c}\text { Partners are } \\
\text { strongly } \\
\text { committed to the } \\
\text { JV operation }\end{array}$ & $\begin{array}{c}\text { Partners are } \\
\text { strongly } \\
\text { committed to the } \\
\text { JV operation }\end{array}$ \\
\hline Level of trust & $\begin{array}{c}\text { Medium level of } \\
\text { trust }\end{array}$ & $\begin{array}{c}\text { Medium level of } \\
\text { trust }\end{array}$ & $\begin{array}{l}\text { High level of } \\
\text { trust }\end{array}$ & $\begin{array}{l}\text { Relatively low } \\
\text { level of trust }\end{array}$ & $\begin{array}{l}\text { Relatively low } \\
\text { level of trust }\end{array}$ & $\begin{array}{c}\text { Low level of } \\
\text { trust }\end{array}$ & $\begin{array}{c}\text { Medium level of } \\
\text { trust }\end{array}$ & $\begin{array}{c}\text { Relatively high } \\
\text { level of trust }\end{array}$ & $\begin{array}{l}\text { High level of } \\
\text { trust }\end{array}$ \\
\hline $\begin{array}{l}\text { Conflicts between } \\
\text { partners }\end{array}$ & $\begin{array}{c}\text { Medium level of } \\
\text { conflicts between } \\
\text { partners }\end{array}$ & $\begin{array}{c}\text { Relatively high } \\
\text { level of conflicts } \\
\text { between partners }\end{array}$ & $\begin{array}{c}\text { Relatively low } \\
\text { level of conflicts } \\
\text { between partners }\end{array}$ & $\begin{array}{c}\text { Medium level of } \\
\text { conflicts between } \\
\text { partners }\end{array}$ & $\begin{array}{c}\text { Low level of } \\
\text { conflicts between } \\
\text { partners }\end{array}$ & $\begin{array}{c}\text { Low level of } \\
\text { conflicts between } \\
\text { partners }\end{array}$ & $\begin{array}{c}\text { Medium level of } \\
\text { conflicts between } \\
\text { partners }\end{array}$ & $\begin{array}{c}\text { Relatively low } \\
\text { level of conflicts } \\
\text { between partners }\end{array}$ & $\begin{array}{c}\text { Low level of } \\
\text { conflicts between } \\
\text { partners }\end{array}$ \\
\hline $\begin{array}{l}\text { Sales orientation at } \\
\text { operation stage }\end{array}$ & $\begin{array}{c}25-49 \% \text { of the } \\
\text { total sales } \\
\text { directed to the } \\
\text { target country }\end{array}$ & $\begin{array}{c}75-100 \% \text { of the } \\
\text { total sales } \\
\text { directed to the } \\
\text { target country }\end{array}$ & $\begin{array}{l}5-24 \% \text { of the } \\
\text { total sales } \\
\text { directed to the } \\
\text { target country }\end{array}$ & $\begin{array}{c}75-100 \% \text { of the } \\
\text { total sales } \\
\text { directed to the } \\
\text { target country }\end{array}$ & $\begin{array}{l}5-24 \% \text { of the } \\
\text { total sales } \\
\text { directed to the } \\
\text { target country }\end{array}$ & $\begin{array}{l}50-74 \% \text { of the } \\
\text { total sales } \\
\text { directed to the } \\
\text { target country }\end{array}$ & $\begin{array}{l}5-24 \% \text { of the } \\
\text { total sales } \\
\text { directed to the } \\
\text { target country }\end{array}$ & $\begin{array}{c}75-100 \% \text { of the } \\
\text { total sales } \\
\text { directed to the } \\
\text { target country }\end{array}$ & $\begin{array}{c}100 \% \text { of the total } \\
\text { sales directed to } \\
\text { the target } \\
\text { country }\end{array}$ \\
\hline Total sales (Meur) & $10-49$ & less than 10 & less than 10 & less than 10 & $10-49$ & less than 10 & $10-49$ & n.a. & n.a. \\
\hline
\end{tabular}


Results of IJV performance

\begin{tabular}{|c|c|c|c|c|c|c|c|c|c|}
\hline \multicolumn{10}{|c|}{ CASES } \\
\hline & $\mathbf{A}$ & B & $\mathrm{C}$ & D & $\mathbf{E}$ & $\mathbf{F}$ & G & $\mathbf{H}$ & I \\
\hline $\begin{array}{l}\text { Financial } \\
\text { performance }\end{array}$ & $\begin{array}{l}\text { Relatively high } \\
\text { satisfaction }\end{array}$ & $\begin{array}{c}\text { Relatively high } \\
\text { satisfaction }\end{array}$ & $\begin{array}{c}\text { Medium level of } \\
\text { satisfaction }\end{array}$ & $\begin{array}{c}\text { Relatively high } \\
\text { satisfaction }\end{array}$ & $\begin{array}{l}\text { Relatively high } \\
\text { satisfaction }\end{array}$ & $\begin{array}{l}\text { Relatively low } \\
\text { satisfaction }\end{array}$ & $\begin{array}{c}\text { Relatively high } \\
\text { satisfaction }\end{array}$ & $\begin{array}{c}\text { Medium level of } \\
\text { satisfaction }\end{array}$ & $\begin{array}{c}\text { Medium level of } \\
\text { satisfaction }\end{array}$ \\
\hline Market position & $\begin{array}{c}\text { smaller than } 5 \text { of } \\
\text { the biggest firms } \\
\text { in the market }\end{array}$ & Market leader & $\begin{array}{c}\text { smaller than } 5 \text { of } \\
\text { the biggest firms } \\
\text { in the market }\end{array}$ & $\begin{array}{c}\text { smaller than } 5 \text { of } \\
\text { the biggest firms } \\
\text { in the market }\end{array}$ & $\begin{array}{l}\text { Within } 2-5 \\
\text { biggest firms }\end{array}$ & $\begin{array}{c}\text { smaller than } 5 \text { of } \\
\text { the biggest firms } \\
\text { in the market }\end{array}$ & Market leader & $\begin{array}{c}\text { Within } 2-5 \\
\text { biggest firms }\end{array}$ & n.a. \\
\hline Sales level & $\begin{array}{c}\text { Relatively high } \\
\text { satisfaction on } \\
\text { level of sales }\end{array}$ & $\begin{array}{c}\text { Relatively high } \\
\text { satisfaction on } \\
\text { level of sales }\end{array}$ & $\begin{array}{c}\text { Medium level of } \\
\text { satisfaction on } \\
\text { level of sales }\end{array}$ & $\begin{array}{c}\text { High level of } \\
\text { satisfaction on } \\
\text { level of sales }\end{array}$ & $\begin{array}{c}\text { Relatively high } \\
\text { satisfaction on } \\
\text { level of sales }\end{array}$ & $\begin{array}{c}\text { Medium level of } \\
\text { satisfaction on } \\
\text { level of sales }\end{array}$ & $\begin{array}{c}\text { Relatively high } \\
\text { satisfaction on } \\
\text { level of sales }\end{array}$ & $\begin{array}{c}\text { Relatively high } \\
\text { satisfaction on } \\
\text { level of sales }\end{array}$ & $\begin{array}{c}\text { Medium level of } \\
\text { satisfaction on } \\
\text { level of sales }\end{array}$ \\
\hline Market share & $\begin{array}{c}\text { Medium level of } \\
\text { satisfaction on } \\
\text { market share }\end{array}$ & $\begin{array}{c}\text { Medium level of } \\
\text { satisfaction on } \\
\text { market share }\end{array}$ & $\begin{array}{c}\text { Medium level of } \\
\text { satisfaction on } \\
\text { market share }\end{array}$ & $\begin{array}{c}\text { High level of } \\
\text { satisfaction on } \\
\text { market share }\end{array}$ & $\begin{array}{c}\text { High level of } \\
\text { satisfaction on } \\
\text { market share }\end{array}$ & $\begin{array}{c}\text { Medium level of } \\
\text { satisfaction on } \\
\text { market share }\end{array}$ & $\begin{array}{c}\text { Relatively high } \\
\text { satisfaction on } \\
\text { market share }\end{array}$ & $\begin{array}{c}\text { Medium level of } \\
\text { satisfaction on } \\
\text { market share }\end{array}$ & $\begin{array}{c}\text { Medium level of } \\
\text { satisfaction on } \\
\text { market share }\end{array}$ \\
\hline Overall satisfaction & $\begin{array}{l}\text { Relatively high } \\
\text { satisfaction }\end{array}$ & $\begin{array}{c}\text { Relatively high } \\
\text { satisfaction }\end{array}$ & $\begin{array}{l}\text { Relatively high } \\
\text { satisfaction }\end{array}$ & $\begin{array}{c}\text { Medium level of } \\
\text { satisfaction }\end{array}$ & $\begin{array}{l}\text { Relatively high } \\
\text { satisfaction }\end{array}$ & $\begin{array}{c}\text { Medium level of } \\
\text { satisfaction }\end{array}$ & $\begin{array}{c}\text { Medium level of } \\
\text { satisfaction }\end{array}$ & $\begin{array}{c}\text { Medium level of } \\
\text { satisfaction }\end{array}$ & $\begin{array}{c}\text { Medium level of } \\
\text { satisfaction }\end{array}$ \\
\hline
\end{tabular}

Source: own

Tab. 5: Ranking of IJV performance

\begin{tabular}{|c|c|c|c|c|c|c|c|c|c|}
\hline \multicolumn{10}{|c|}{ CASES } \\
\hline & $\mathbf{A}$ & B & $\mathrm{C}$ & D & E & F & G & H & I \\
\hline \begin{tabular}{|l|}
$\begin{array}{l}\text { Financial } \\
\text { performance }\end{array}$ \\
\end{tabular} & 3 & 3 & 1 & 3 & 3 & 0 & 3 & 1 & 1 \\
\hline Market position & 1 & 5 & 1 & 1 & 3 & 1 & 5 & 3 & n.a. \\
\hline Sales level & 3 & 3 & 1 & 5 & 3 & 1 & 3 & 3 & 1 \\
\hline \begin{tabular}{|l|} 
Market share \\
\end{tabular} & 1 & 1 & 1 & 5 & 5 & 1 & 3 & 1 & 1 \\
\hline Overall satisfaction & 3 & 3 & 3 & 1 & 3 & 1 & 1 & 1 & 1 \\
\hline Overall ranking & 11 & 15 & 7 & 15 & 17 & 4 & 15 & 9 & n.a. \\
\hline
\end{tabular}

Source: own

The results of IJV performance are presented in Table 4. Results from all nine case studies from company A to company I have been summarized. Table 4 contains subjective IJV performance measures such as financial performance, market position, sales level, market share, and overall satisfaction. The results of these subjective measures represent a Finnish parent perspective i.e. they were obtained from Finnish managers in the IJVs. In Table 5 a numerical ranking is presented by assigning different weights (on a 0-1-3-5 scale) to individual performance results. For example in financial performance measure high satisfaction is assigned a weight 5 and relatively high satisfaction is assigned with 3 . Medium level of satisfaction is given a weight 1 and low level of satisfaction will be given 0 . Other performance results are assigned weights in a similar way. By simply adding up all weights we get the overall ranking for each case. In Table 5 case $E$ has the highest rank 17. Cases $B, D$ and $G$ have the second rank with a number 15. Case $F$ has the worst rank.

For the analysis of the results we will start from results at IJV formation stage. From Table 2 we can see that the size of the Finnish partners in IJVs vary considerably. IJVs $B, G$, and $H$ ( $G$ and $H$ were established by the same Finnish firm) were established by larger Finnish multinational corporations (MNCs) while other Finnish companies are small and medium enterprises (SMEs). The Finnish MNCs have relatively more FDI, IJV and TC experience than SMEs and they all have a long term focus (intended duration of the IJV). These MNCs are also significantly larger than their Chinese partners. They have a number of motivations to enter China and they have a higher ownership share than their Chinese partners (majority owned 
IJVs). As a result in Table 4 both IJVs B and $G$ were evaluated to have excellent financial performance and the two companies showed relatively high satisfaction. Company $\mathrm{H}$ showed a medium level of satisfaction. All of them had a leading market position partly due to its large size scale effect. All of them also showed high level of satisfaction with the level of sales and market share. For overall satisfaction company $B$ showed relatively high satisfaction while companies $G$ and $H$ showed medium level of satisfaction. In table 5 companies $B$ and $G$ have the same weight 15 while company $H$ has a weight 9 . They all showed relatively good performance. We argue that all performance measures should be analyzed and combined to give a more solid result. Therefore by the combination of all the performance measures we think FDI experience is an important factor in IJV performance. For the factor timing of entry, four companies had investment after year 2000 i.e. companies A, E, G(H) and I. Among them companies A, E, G showed relatively high satisfaction on financial performance and companies $\mathrm{H}$ and I showed medium level of satisfaction. They also showed either relatively high satisfaction or medium level satisfaction on measures of sales, market share, and overall satisfaction. From this analysis we can also say timing of entry also affects IJV performance and early movers tend to outperform latecomers in a foreign market because their operations tend to be more stable and partners may know each other better after a few years leading to better performance. All other factors such as establishment mode and main motivation etc. do not show a consistent result.

Factors at IJV operation stage also affect performance. For partner commitment, companies C and $\mathrm{F}$ have low partner commitment and they have the worst ranks in Table 5 with an overall ranking number 7 and 4 respectively. Sales and market share for both companies also showed medium level of satisfaction. From the analysis we can conclude low partner commitment tends to lead to low level of satisfaction in IJV performance. All other factors at this stage including strategic control, operational control, trust, conflicts, and sales orientation, didn't show a consistent result.

Company $E$ is an exception in terms of intended duration of IJV and it is planned for only 2-5 years. Timing of entry was 2003 and the investment type was acquisition. In this case Finnish parent had the highest ownership percentage at formation stage (85\%) among all nine cases. At IJV operation stage Finnish parent in company $E$ had high strategic and operational controls and strong mutual commitment. Conflicts between partners were low and only $5-24 \%$ of the total sales were directed to the target country. In terms of performance the Finnish parent showed high level of satisfaction on all performance measures. In this case the Finnish parent company is a medium sized company and had the investment in China in 2003 and the commitment is strong from both partners. Therefore the two key factors i.e. timing of entry and partner commitment are still valid in this case.

From the above case studies and analyses we find that FDI experience and timing of entry are the key success factors at IJV formation stage and partner commitment is the key success factor at IJV operation stage. Other factors either did not affect IJV performance or did not show a consistent result.

\section{Conclusions}

IJVs are commonly used to enter the Chinese market and IJVs have received a great academic and managerial interest. Accordingly, there is an increasing interest to study the key factors or determinants underlying IJV performance. However, in the existing IJV performance research the foreign parent firms are mainly from major developed countries such as USA. There is very little research on firms from small developed European countries such as Finland. This paper extends current IJV performance research by studying nine Finnish-Chinese IJVs operating in Mainland China. In the literature review section of this paper an overview of IJV theories, determinants of IJV performance and the pros and cons of objective and subjective IJV performance measures, were made. Based on the literature review and our ongoing research an overview of potential determinants of IJV performance were presented grouped into three main categories: IJV local environment, IJV formation stage, and IJV operation stage. A conceptual model for the investigation of IJV performance determinants was presented. The empirical part of the paper consisted of nine Finnish-Chinese IJV case studies. The results 
show that FDI experience and timing of entry (age of IJV unit) are the key success factors at IJV formation stage while partner commitment is the key factor at IJV operation stage. This implies that these factors are crucial to IJV success and should be paid special attention to in the formation of IJVs and in the operation process thereafter. The results support some of the earlier studies [46], [4], [43] which argue that $\mathrm{FDI}(\mathrm{IJV})$ experience, timing of entry and mutual commitment are the key determinants of IJV performance. All other factors are either associated with the identified key factors or they didn't show a consistent result.

As usual, there are some limitations in this research. First we only managed to have nine cases and they are not enough for more extensive generalisations. Secondly, all the cases were Finnish-Chinese IJVs, thus one has to be cautious with generalisations of the results to IJVs established by firms from other smaller developed economies in China. Thirdly, there might be some tradeoffs between the various factors or determinants of IJV performance. Therefore future research may include more Finnish-Chinese IJVs to allow for a quantitative analysis of these factors on IJV performance. Special attention should be paid to the possible tradeoffs between these factors. Moreover, As Madhok [51] suggests in the decade award winning article of Journal of International Business Studies, current research trend also calls for a shift of focus from separate factors such as ownership to relational dynamics in IJV performance. Therefore future research directions can also include more embedded case studies to reveal interfirm or interpartner dynamics that might be fundamental factors underlying successful IJV performance. Furthermore, the future studies should analyze IJVs in China established by firms from other smaller developed European economies like from other Nordic countries and e.g. from Austria or from Belgium or Greece.

\section{References}

[1] BALAKRISHNAN, S., KOZA, M.P. Information asymmetry, adverse selection and joint ventures theory and evidence. Journal of Economic Behaviour and Organization. 1993, Vol. 20, Iss. 1, pp. 99-117. ISSN 0167-2681.

[2] BARKEMA, H.G., VERMEULEN, F. What differences in the cultural backgrounds of partners are detrimental for international joint ventures? Journal of International Business Studies. 1997, Vol. 28, Iss. 4, pp. 845-864. ISSN 0047-2506.

[3] BEAMISH, P.W. The characteristics of joint ventures in the People's Republic of China. Journal of International Marketing. 1993, Vol. 1, pp. 29-48. ISSN 1069-031X.

[4] BEAMISH, P.W. Multinational joint ventures in developing countries. London: Routledge, 1998. ISBN 0415003946.

[5] BEAMISH, P.W. Publishing international research for impact. Asia Pacific Journal of Management. 2006, Vol. 23, pp. 29-46. ISSN 0217-4561.

[6] BLASKOVA, M. Correlations between the increase in motivation and increase in quality. E+M Ekonomie a Management. 2009, Vol. 12, Iss. 4, pp. 54-68. ISSN 1212-3609.

[7] BURGER, P. The level of regionalization of innovation policies and their impact on innovation performance of regions. E+M Ekonomie a Management. 2010, Vol. 13, Iss. 1, pp. 23-36. ISSN 1212-3609.

[8] BURGERS, W., PADGETT, D. Understanding environmental risk for IJVs in China. Management International Review. 2009, Vol. 49, Iss. 3, pp. 337-358. ISSN 0938-8249.

[9] CALANTONE, R.J., ZHAO, Y.S. Joint ventures in China: a comparative study of Japanese, Korean, and US partners. Journal of International Marketing. 2000, Vol. 9, Iss. 1, pp.1-23. ISSN 1069-031X. [10] CHILD, J., FAULKNER, D. Strategies of Cooperation. New York: Oxford University Press, 1998. ISBN 0198774842.

[11] CHOW, C.W., HARRISON, G.L., MCKINNON, J.L., WU, A. Cultural influences on informal information sharing in Chinese and Anglo-American organizations: an exploratory study. Accounting, Organizations and Society. 1999, Vol. 24, Iss. 7, pp. 561-582. ISSN 0361-3682.

[12] CONTRACTOR, F.J., KUNDU, S.K. Choice in a world of alliances: analyzing organizational forms in the international hotel sector. Journal of International Business Studies. 1998, Vol. 29, Iss. 2, pp. 325-358. ISSN 0047-2506.

[13] China Statistical Yearbook. Beijing: China National Statistics Bureau, 2008. ISBN 750375530X. [14] CURRALL, S.C., INKPEN, A.C. A multilevel approach to trust in joint ventures. Journal of International Business Studies. 2002, Vol. 33, Iss. 3, pp. 479-495. ISSN 0047-2506.

[15] DAS, T.K., TENG, B.S. A resource-based theory of strategic alliances. Journal of Management. 2000, Vol. 26, Iss. 1, pp. 31-61. ISSN 0149-2063. 
[16] DHANARAJ, C., LYLES, M.A., STEENSMA, H.K., TIHANYI, L. Managing tacit and explicit knowledge transfer in IJVs: the role of relational embeddedness and the impact on performance. Journal of International Business Studies. 2004, Vol. 35, Iss. 5, pp. 428-442. ISSN 0047-2506.

[17] DUAN, J., SHUAI, C. Ownership, Control, and performance of U.S.-China joint ventures: A longitudinal study. Journal of Applied Management and Entrepreneurship. 2007, Vol. 12, Iss. 1, pp. 24-35. ISSN 1077-1158.

[18] EISENHARDT, K.M. Building theory from case study research. Academy of Management Review. 1989, Vol. 14, Iss. 4, pp. 432-550. ISSN 0363-7425.

[19] EISENHARDT, K.M., SEHOONHOVEN, C.B. Resource-based view of strategic alliance formation: strategic and social effects in entrepreneurial firms. Organizational Science. 1996, Vol. 7, Iss. 2, pp. 136-150. ISSN 1047-7039.

[20] EROGLU, D., YAVAS, U. Determinants of satisfaction with partnership in international joint ventures: a channels perspective. Journal of Marketing Channels. 1996, Vol. 5, Iss. 2, pp. 6380. ISSN 1046-669X.

[21] GERINGER, J.M., HEBERT, L. Control and performance of international joint ventures. Journal of International Business Studies. 1989, Vol. 20, Iss. 2, pp. 235-254. ISSN 0047-2506.

[22] GERINGER, J.M., HEBERT, L. Measuring performance of international joint ventures. Journal of International Business Studies. 1991, Vol. 22, Iss. 2, pp. 249-263. ISSN 0047-2506.

[23] GLAISTER, K.W., BUCKLEY, P.J. Measures of performance in UK international alliances. Organization Studies. 1998, Vol. 19, Iss. 1, pp. 89-119. ISSN 0170-8406.

[24] GOMES-CASSERES, B. Joint venture instability: is it a problem? Columbia Journal of World Business. 1987, Vol. 22, Iss. 2, pp. 97-102. ISSN 0022-5428.

[25] HENNART, J.F. A transaction costs theory of equity joint ventures. Strategic Management Journal. 1988, Vol. 9, Iss. 4, pp. 361-374. ISSN 1097-0266.

[26] HENNART, J.F., KIM, D.J., ZENG, M. The impact of joint venture status on the longevity of Japanese stakes in U.S. manufacturing affiliates. Organization Science. 1998, Vol. 9, Iss. 3, pp. 382-395. ISSN 1047-7039.

[27] HOFSTEDE, G. Cultures consequences: international differences in work-related values. Newbury Park (CA): Sage, 1980. ISBN 0803913060.
[28] HOFSTEDE, G., BOND, M.H. The Confucius connections: From cultural roots to economic growth. Organization Dynamics. 1988, Vol. 16, Iss. 4, pp. 4-21. ISSN 0090-2616.

[29] HOFSTEDE, G. Cultures consequences: Comparing values, behaviours, institutions, and organizations across nations. Thousand Oaks: Sage Publications, 2001. ISBN 0803973241.

[30] INKPEN, A.C., CROSSNAN, M.M. Believing in seeing: joint ventures and organizational learning. Journal of Management Studies. 1995, Vol. 32, Iss. 5, pp. 595-618. ISSN 1467-6486.

[31] INKPEN, A.C., CURRALL, S.C. International joint venture trust. In BEAMISH, P.W., KILLING, J.P. (Eds.). Cooperative strategies: North American perspectives. San Francisco: New Lexington Press, 1997. ISBN 0-7879-0813-4.

[32] INKPEN, A.C., DINUR, A. Knowledge management processes and international joint ventures. Organization Science. 1998, Vol. 9, Iss. 4, pp. 454-468. ISSN 1047-7039.

[33] INKPEN, A.C., CURRALL, S.C. The coevolution of trust, control, and learning in joint ventures. Organization Science. 2004, Vol. 15, Iss. 5, pp. 586-599. ISSN 1047-7039.

[34] JANECEK, V., HYNEK, J. Incentive system as a factor of firms' efficiency improvement. $E+M$ Ekonomie a Management. 2010, Vol. 13, Iss. 1, pp. 76-90. ISSN 1212-3609.

[35] KOGUT, B. Joint ventures: Theoretical and empirical perspectives. Strategic Management Journal. 1998, Vol. 9, Iss. 4, pp. 319-332. ISSN 1097-0266. [36] KUMAR, S., SETH, A. The design of coordination and control mechanisms for managing joint venture-parent relations. Strategic Management Journal. 1998, Vol. 19, Iss. 6, pp. 579-599. ISSN 1097-0266.

[37] LANE, P.J., SALK J.E., LYLES, M.A. Absorptive capacity, learning, and performance in international joint ventures. Strategic Management Journal. 2001, Vol. 22, Iss. 12, pp. 1139-1161. ISSN 1097-0266.

[38] LARIMO, J. International joint venture performance: Impact of performance measures and foreign parent, target country and investment specific variables on performance. In CLIQUET, G., HENDRIKS, G., TUUNANEN, M., WINDSPERGER, J. (Eds.). Economics and Management of Networks: Franchising, Strategic Alliances and Co-operatives. Springer Verlag, 2007. pp. 393-418. ISBN 3790817570.

[39] LEE, C., BEAMISH, P.W. The characteristics and performance of Korean joint ventures in LDCs. 
Journal of International Business Studies. 1995, Vol. 26, Iss. 3, pp. 637-654. ISSN 0047-2506.

[40] LI, M., ZHANG, Y., JING, R. Does ownership and culture matter to joint venture success? International Management Review. 2008, Vol. 4, Iss. 1, pp. 88-101. ISSN 1551-6849.

[41] LI, J., LAM, K., QIAN, G. Does culture affect behaviour and performance of firms? The case of joint ventures in China. Journal of International Business Studies. 2001, Vol. 32, Iss. 1, pp. 115-131. ISSN 0047-2506.

[42] LI, J., ZHOU, C. Dual-edged tools of trade: How international joint ventures help and hinder capability building of Chinese firms. Journal of World Business. 2008, Vol. 43, Iss. 4, pp. 463-474. ISSN 1090-9516.

[43] LIN, X., GERMAIN, R. Predicting international joint venture interaction frequency in U.S.-Chinese ventures. Journal of International Marketing. 1999, Vol. 7, Iss. 2, pp. 5-23. ISSN 1069-031X.

[44] LU, L.T., LEE, Y.H. The effect of culture on the management style and performance of international joint ventures in China: the perspective of foreign parent firms. International Journal of Management. 2005, Vol. 22, Iss. 3, pp. 452-467. ISSN 0813-0183.

[45] LU, L.T., SHIANG, J. Conflict resolution strategy between foreign and local partners in joint ventures in China. Journal of American Academy of Business. 2006, Vol. 8, Iss. 1, pp. 236-240. ISSN 1540-1200.

[46] LUO, Y. Timing of investment and international expansion performance in China. Journal of International Business Studies. 1997, Vol. 29, Iss. 2, pp. 391-407. ISSN 0047-2506.

[47] LUO, Y., SHENKAR, O., NYAW, M.K. A dualparent perspective on control and performance in international joint ventures: Lessons from a developing economy. Journal of International Business Studies. 2001, Vol. 32, Iss. 1, pp. 41-58. ISSN 0047-2506.

[48] LUO, Y. Procedural fairness and interfirm cooperation in strategic alliances. Strategic Management Journal. 2008, Vol. 29, Iss. 1, pp. 27-46. ISSN 1097-0266.

[49] LYLES, M.A., SALK, J.E. Knowledge acquisition from foreign parents in international joint ventures: An empirical examination in the Hungarian context. Journal of International Business Studies. 1996, Vol. 29, Iss. 2, pp. 154-174. ISSN 0047-2506.

[50] MADHOK, A. Revisiting multinational firms' tolerance for joint ventures: a trust-based approach.
Journal of International Business Studies. 1995, Vol. 26, Iss. 1, pp. 117-137. ISSN 0047-2506.

[51] MADHOK, A. Revisiting multinational firms' tolerance for joint ventures: a trust-based approach. Journal of International Business Studies. 2006, Vol. 37, pp. 30-43. ISSN 0047-2506.

[52] MATHEWS, J.A. Competitive advantages of the latecomer firm: A resource-based account of industrial catch-up strategies. Asia Pacific Journal of Management. 2002, Vol. 19, pp. 467-488. ISSN 0217-4561.

[53] MJOEN, H., TALLMAN, S. Control and performance in international joint ventures. Organization Science. 1997, Vol. 8, Iss. 3, pp. 257-274. ISSN 1047-7039.

[54] NIPPA, M., BEECHLER, S., KLOSSEK, A. Success factors for managing international joint ventures: a review and an integrative framework. Management and Organization Review. 2007, Vol. 3, Iss. 2, pp. 277-310. ISSN 1740-8784.

[55] OSLAND, E.G., CAVUSGIL, S.T. Performance issues in US-China joint ventures. California Management Review. 1996, Vol. 38, Iss. 2, pp. 106-130. ISSN 0008-1256.

[56] PARK, S.H., UNGASON, G.R. The effect of national culture, organizational complementarity, and economic motivation on joint venture dissolution. Academy of Management Journal. 1997, Vol. 40, pp. 279-307. ISSN 0001-4273.

[57] PARK, S.H., UNGASON, G.R. Interfirm rivalry and managerial complexity: a conceptual framework of alliance failure. Organisation Science. 2001, Vol. 12, Iss. 1, pp. 37-53. ISSN 1047-7039. [58] RAMANATHAN, K., SETH, A., THOMAS, H. Explaining joint ventures: alternative theoretical perspectives. In BEAMISH, P.W., KILLING, J.P. (Eds.). Cooperative strategies: North American perspectives. San Francisco: New Lexington Press, 1997. ISBN 0-7879-0813-4.

[59] REISSOVA, A. Personnel Evaluation as a controlling tool of the management of the work efficiency. E+M Ekonomie a Management. 2010, Vol. 13, Iss. 1, pp. 91-102. ISSN 1212-3609.

[60] REN, H., GRAY, B., KIM, K. Performance of international joint ventures: what factors really make a different and how? Journal of Management. 2009, Vol. 35, Iss. 3, pp. 805-832. ISSN 0149-2063.

[61] REUER, J.J., MILLER, K.D. Agency costs and the performance implications of international joint venture internalization. Strategic Management Journal. 1997, Vol. 18, Iss. 6, pp. 425-438. ISSN 1097-0266. 


\section{Ekonomika a management}

[62] ROBSON, M.J., LEONIDOU, L.C., KATSIKEAS, C.S. Factors influencing international joint venture performance: theoretical perspectives, assessment, and future directions. Management International Review. 2002, Vol. 42, pp. 385-418. ISSN 0938-8249.

[63] STEENSMA, H.K., LYLES, M.A. Explaining IJV survival in a transitional economy through social exchange and knowledge-based perspectives. Strategic Management Journal. 2000, Vol. 21, Iss. 8 , pp. 831-851. ISSN 1097-0266.

[64] UNCTAD (United Nations Conference on Trade and Development). Prospects for FDI flows, transnational corporation strategies and promotion policies: 2004-2007 [online]. Geneva: UNCTAD, 2004 [cit. 2012-08-05]. Available from: http://unctad.org/en/Docs/ tdxibpd8_en.pdf.

[65] U.S.-China Business Council. Foreign Investment in China, Forecast [online]. 2008 [cit. 2012-01-12]. Available from: http://www.uschina.org/info/ forecast/2008/foreign-investment.htm.

[66] YAN, A., GRAY, B. Bargaining power, management control, and performance in United States-China joint ventures: A comparative case study. Academy of Management Journal. 1994, Vol. 37, Iss. 6, pp. 1478-1517. ISSN 0001-4273.

[67] YAN, A., ZENG, M. International joint venture instability: A critique of previous research, a reconceptulization, and directions for future research. Journal of International Business Studies. 1999, Vol. 30, Iss. 2, pp. 397-414. ISSN 0047-2506.

[68] YIN, R.K. Case study research: design and methods. 3rd ed. Thousand Oaks (CA): SAGE Publications, 2002. ISBN 0761925538.

[69] ZHAN, W., LUO, Y. Performance implications of capacity exploitation and upgrading in international joint ventures. Management International Review. 2008, Vol. 48, Iss. 2, pp. 227-253. ISSN 0938-8249.

[70] ZICH, R. Success-ability based conception and its view of strategy. $E+M$ Ekonomie a Management. 2010, Vol. 13, Iss. 1, pp. 60-75. ISSN 1212-3609.

\section{Xiaosong Zheng, Ph.D.} Shanghai University

Sydney Institute of Language and Commerce xiaosong.zheng@shu.edu.cn

and

Tallinn University of Technology

School of Economics and Business Administration xiaosong.zheng@ttu.ee

Prof. Jorma Larimo, Ph.D. University of Vaasa

Faculty of Business Studies jorma.larimo@uwasa.fi 


\title{
Abstract
}

\section{IDENTIFYING KEY SUCCESS FACTORS FOR INTERNATIONAL JOINT VENTURES IN CHINA: A FOREIGN PARENT PERSPECTIVE FROM FINNISH FIRMS}

\author{
Xiaosong Zheng, Jorma Larimo
}

International Joint Venture (IJV) has been one of the main foreign market entry approaches in the last decade and this is particularly true for entry to the huge Chinese market. Although IJVs have been a very commonly used entry form many studies have indicated that the IJVs have not reached the goals set for them or they have clearly failed. Recently there has been also a growing interest to examine the performance and determinants of successful IJVs in China from major developed countries. The studies have so far mainly focused on IJVs where the foreign partners are either from Asian countries or from big western economies like from the USA whereas research focused on IJVs established by firms from small developed European economies like from various Nordic countries has been extremely limited. This paper tries to shed some light on this gap by analyzing the performance and key success factors of Finnish-Chinese IJVs from a Finnish parent perspective. In the paper a conceptual model to examine key IJV performance determinants is first built up and then we apply this model in the analysis of a few Finnish-Chinese IJVs. The results of the study show that IJV performance depends on the measure of the performance. Focusing on management evaluation of performance the FDI experience and timing of entry are found to be the key success factors at IJV formation stage while partner commitment is the key success factor at IJV operation stage. At the end of the paper, conclusions are made and limitations are discussed together with an outline of future research directions.

Key Words: Success factors, IJV, performance, China, Finland.

JEL Classification: M16, M31.

DOI: 10.15240/tul/001/2014-2-008 